\title{
An Overview of Parameters Controlling the Decomposition and Degradation of Ti-Based $M_{n+1} A X_{n}$ Phases
}

\author{
It-Meng Low \\ Department of Applied Physics, Curtin University, GPO Box U1987, Perth, WA 6845, Australia; \\ j.low@curtin.edu.au; Tel.: +61-8-9266-7544
}

Received: 1 December 2018; Accepted: 1 February 2019; Published: 4 February 2019

check for updates

\begin{abstract}
A critical overview of the various parameters, such as annealing atmospheres, pore microstructures, and pore sizes, that are critical in controlling the decomposition kinetics of Ti-based MAX phases is given in this paper. Ti-based MAX phases tend to decompose readily above $1400{ }^{\circ} \mathrm{C}$ during vacuum annealing to binary carbide (e.g., $\mathrm{TiC}_{x}$ ) or binary nitride (e.g., $\mathrm{TiN}_{x}$ ), primarily through the sublimation of $A$ elements such as $\mathrm{Al}$ or $\mathrm{Si}$, forming in a porous $\mathrm{MX}_{x}$ surface layer. Arrhenius Avrami equations were used to determine the activation energy of phase decomposition and to model the kinetics of isothermal phase decomposition. Ironically, the understanding of phase decomposition via exfoliating or selective de-intercalation by chemical etching formed the catalyst for the sensational discovery of Mxenes in 2011. Other controlling parameters that also promote decomposition or degradation as reported in the literature are also briefly reviewed and these include effects of pressure and ion irradiations.
\end{abstract}

Keywords: MAX phases; kinetics of decomposition; activation energy; vapor pressure; Avrami equation; Arrhenius equation; damage-tolerance

\section{Introduction}

MAX phases exhibit a unique combination of characteristics of both ceramics and metals and have unusual mechanical, electrical and thermal properties [1-6]. These materials are nano-layered ceramics with the general formula $M_{n+1} A X_{n}(n=1-3)$, where $M$ is an early transition metal, $A$ is a group $A$ element, and $X$ is either carbon and/or nitrogen. Similar to ceramics, they possess low density, low thermal expansion coefficient, high modulus and high strength, and good high-temperature oxidation resistance. Like metals, they are good electrical and thermal conductors, readily machinable, tolerant to damage, and resistant to thermal shock. The unique combination of these interesting properties enables these ceramics to be promising candidate materials for use in diverse fields which include automobile engine components, heating elements, rocket engine nozzles, aircraft brakes, racing car brake pads and low-density armor. In addition, MAX phases such as $\mathrm{Ti}_{2} \mathrm{AlC}$ and $\mathrm{Ti}_{3} \mathrm{SiC}_{2}$ have been shown to exhibit sufficient damage tolerance to irradiations which renders them as promising materials for high-temperature nuclear applications [7-9].

However, the high-temperature thermochemical stability in MAX phases has hitherto generated much controversy among researchers. For instance, several researchers have reported that $\mathrm{Ti}_{3} \mathrm{SiC}_{2}$ becomes unstable at temperatures greater than $1400{ }^{\circ} \mathrm{C}$ in an inert atmosphere (e.g., vacuum, argon, or nitrogen), by dissociating into $\mathrm{Si}, \mathrm{TiC}_{x}$ and $/$ or $\mathrm{Ti}_{5} \mathrm{Si}_{3} \mathrm{C}_{x}$ [10-15]. A similar phenomenon has been observed for $\mathrm{Ti}_{3} \mathrm{AlC}_{2}$ and $\mathrm{Ti}_{2} \mathrm{AlN}$, whereby they decompose under vacuum to form $\mathrm{TiC}_{x}$ and $\mathrm{TiN}_{x}$, respectively [16-20].

With regards to other studies, Zhang et al. [21] have reported $\mathrm{Ti}_{3} \mathrm{SiC}_{2}$ to be thermally stable up to $1300{ }^{\circ} \mathrm{C}$ in nitrogen but that above this temperature drastic degradation and damage occurs due to 
surface decomposition. Feng et al. [22] annealed the $\mathrm{Ti}_{3} \mathrm{SiC}_{2}$-based bulk samples at $1600{ }^{\circ} \mathrm{C}$ for $2 \mathrm{~h}$ and $2000{ }^{\circ} \mathrm{C}$ for $0.5 \mathrm{~h}$ under vacuum $\left(10^{-2} \mathrm{~Pa}\right)$ and found that $\mathrm{TiC}_{x}$ was the only phase remaining on the surface. According to Gao et al. [23] the propensity of the decomposition of $\mathrm{Ti}_{3} \mathrm{SiC}_{2}$ to $\mathrm{TiC}_{x}$ is related to the vapor pressure of $\mathrm{Si}$, i.e., the atmosphere to which the $\mathrm{Ti}_{3} \mathrm{SiC}_{2}$ is exposed. They believe that the partial pressure of $\mathrm{Si}$ plays an important role in maintaining the stability of $\mathrm{Ti}_{3} \mathrm{SiC}_{2}$ given that it has a high propensity to decompose in and $\mathrm{N}_{2}, \mathrm{O}_{2}$, or $\mathrm{CO}$ atmosphere at temperatures above $1400{ }^{\circ} \mathrm{C}$. This process of surface-initiated phase decomposition has even been observed to commence as low as $1000-1200{ }^{\circ} \mathrm{C}$ in $\mathrm{Ti}_{3} \mathrm{SiC}_{2}$ thin films during vacuum annealing [24]. The large difference in observed decomposition temperatures between bulk and thin-film $\mathrm{Ti}_{3} \mathrm{SiC}_{2}$ has been attributed to the difference in diffusion length scales involved and measurement sensitivity employed in the respective studies. In addition, $\mathrm{Ti}_{3} \mathrm{SiC}_{2}$ has also been observed to react readily with molten $\mathrm{Al}, \mathrm{Cu}, \mathrm{Ni}$, and cryolite $\left(\mathrm{Na}_{3} \mathrm{AlF}_{6}\right)$ at high temperatures [25].

In contrast, Barsoum and co-workers [26] have shown that $\mathrm{Ti}_{3} \mathrm{SiC}_{2}$ is thermodynamically stable up to at least $1600{ }^{\circ} \mathrm{C}$ in vacuum for $24 \mathrm{~h}$ and in argon atmosphere for $4 \mathrm{~h}$. They further argue that the reduced temperature at which $\mathrm{Ti}_{3} \mathrm{SiC}_{2}$ decomposes, as observed by others, is due to the presence of impurity phases (e.g., Fe or $\mathrm{V}$ ) in the starting powders which interfere with the reaction synthesis of $\mathrm{Ti}_{3} \mathrm{SiC}_{2}$, and thus destabilize it following prolonged annealing in an inert environment [27]. However, mixed results have been reported by Radhakrishnan et al. [28]. In their investigation, $\mathrm{Ti}_{3} \mathrm{SiC}_{2}$ was shown to be stable in a tungsten-heated furnace for $10 \mathrm{~h}$ at $1600{ }^{\circ} \mathrm{C}$ and at $1800{ }^{\circ} \mathrm{C}$ in an argon atmosphere but dissociated to $\mathrm{TiC}_{x}$ under the same conditions when a graphite heater was used.

These conflicting results suggest that the thermochemical stability of MAX phases is still poorly understood, although its susceptibility to thermal decomposition is strongly influenced by factors such as purity of powders and sintered materials, temperature, vapor pressure, atmosphere, and the type of heating elements used. In addition, the nature of the microstructure of the decomposed surface layer formed during annealing remains controversial, especially in relation to the role of pore sizes in the decomposition kinetics at the near surface.

In this paper, we provide a critical overview of the various parameters, such as annealing atmospheres, pore microstructure, and pore size, that are critical in controlling the decomposition kinetics of MAX phases. Other parameters that also cause decomposition or degradation as reported in the literature are briefly reviewed, and these include the effects of pressure and ion irradiations.

\section{Kinetics of Phase Decomposition}

The activation energies calculated from the Arrhenius equation for the five MAX phases and the proposed reactions are summarized and listed in Table 1 . All the calculated activation energies are positive except for that of bulk $\mathrm{Ti}_{3} \mathrm{AlC}_{2}$ [15]. However, when powder of $\mathrm{Ti}_{3} \mathrm{AlC}_{2}$ was used, a positive value of activation energy was obtained, which implies the importance of pore microstructures in the decomposition kinetics. A negative activation energy indicates that the rate of decomposition in $\mathrm{Ti}_{3} \mathrm{AlC}_{2}$ decreased with increasing temperature due to the formation of a dense TiC surface layer with very fine pores $(<1.0 \mu \mathrm{m})$ which exert an increasing resistance to the sublimation process as the temperature increases (Figure 1d). In contrast, a more porous decomposed layer with coarser pores $(>2.0 \mu \mathrm{m})$ formed in other MAX phases and in powdered $\mathrm{Ti}_{3} \mathrm{AlC}_{2}$ which enabled the sublimation of $\mathrm{Al}$ or Si to progress with minimum resistance, thus resulting in an increasing rate of decomposition with temperature (Figure 1a-c). In short, pore size plays a critical role in determining the value of activation energy and the rate of decomposition. Thus, the ability to manipulate the pore microstructure either through densification to reduce pore size or the engineering of pore free microstructure will allow the process of decomposition in MAX phases to be minimized or arrested. 
Table 1. Comparison of the kinetics of decomposition in six MAX-phase samples. Courtesy of AZom.com [10].

\begin{tabular}{cccc}
\hline MAX Phase & $\begin{array}{c}\text { Activation Energy } \\
\left(\mathbf{k J ~ m o l} \mathbf{~ m o l}^{\mathbf{1}}\right.\end{array}$ & $\begin{array}{c}\text { Pore Size } \\
(\boldsymbol{\mu \mathbf { m } )}\end{array}$ & Proposed Reactions \\
\hline $\mathrm{Ti}_{3} \mathrm{SiC}_{2}$ & 169.6 & $1.0-3.0$ & $\mathrm{Ti}_{3} \mathrm{SiC}_{2} \rightarrow 3 \mathrm{TiC}_{0.67}+\mathrm{Si}_{(\mathrm{g})}$ \\
$\mathrm{Ti}_{3} \mathrm{AlC}_{2}$ (bulk) & -71.9 & $0.5-0.8$ & $\mathrm{Ti}_{3} \mathrm{AlC}_{2} \rightarrow 3 \mathrm{TiC}_{0.67}+\mathrm{Al}_{(\mathrm{g})}$ \\
$\mathrm{Ti}_{3} \mathrm{AlC}_{2}$ (powder) & 71.9 & $>1.0$ & $\mathrm{Ti}_{3} \mathrm{AlC}_{2} \rightarrow 3 \mathrm{TiC}_{0.67}+\mathrm{Al}_{(\mathrm{g})}$ \\
$\mathrm{Ti}_{2} \mathrm{AlC}$ & 85.7 & $2.0-10.0$ & $\mathrm{Ti}_{2} \mathrm{AlC} \rightarrow 2 \mathrm{TiC}_{0.5}+\mathrm{Al}_{(\mathrm{g})}$ \\
$\mathrm{Ti}_{2} \mathrm{AlN}$ & 573.8 & $2.0-8.0$ & $\mathrm{Ti}_{2} \mathrm{AlN} \rightarrow 2 \mathrm{TiN}_{0.5}+\mathrm{Al}_{(\mathrm{g})}$ \\
$\mathrm{Ti}_{4} \mathrm{AlN}_{3}$ & 410.8 & $1.8-3.0$ & $\mathrm{Ti}_{4} \mathrm{AlN}_{3} \rightarrow 4 \mathrm{TiN}_{0.75}+\mathrm{Al}_{(\mathrm{g})}$ \\
\hline
\end{tabular}

The kinetics of isothermal phase decomposition as modelled using the Avrami equation and the Avrami exponents $(n)$ of isothermal decomposition of the MAX phases are shown in Table 2. The low values (i.e., $<1$ ) of the exponent indicate that in all cases the decomposition is a highly restricted diffusion process, presumably of $\mathrm{Al}$ or $\mathrm{Si}$ from the bulk of the sample to its surface (from where it enters the vacuum of the furnace).
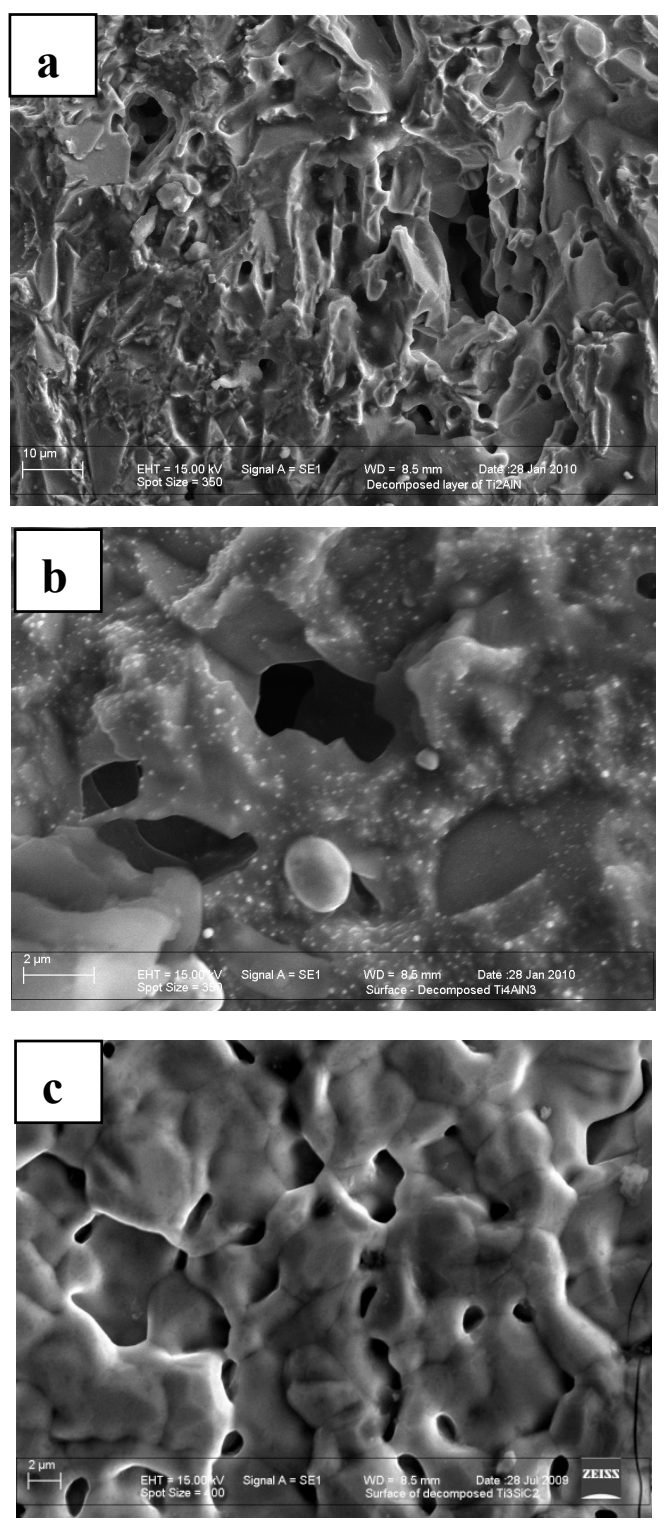

Figure 1. Cont. 


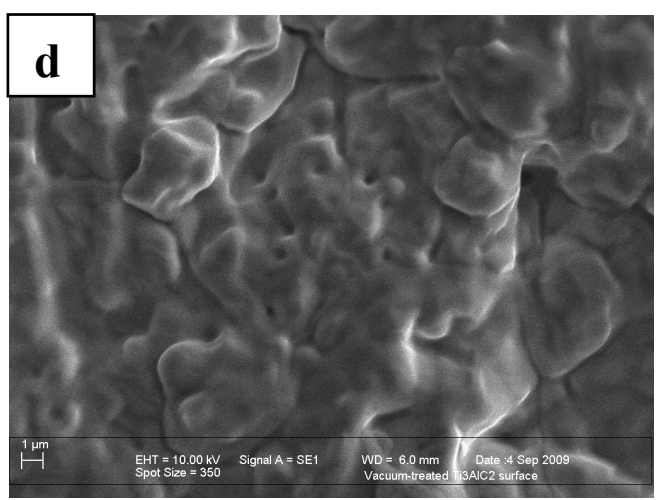

Figure 1. Scanning electron micrographs of the surface microstructures of vacuum-decomposed MAX phases; (a) $\mathrm{Ti}_{2} \mathrm{AlN}$, (b) $\mathrm{Ti}_{4} \mathrm{AlN}_{3}$, (c) $\mathrm{Ti}_{3} \mathrm{SiC}_{2}$, and (d) $\mathrm{Ti}_{3} \mathrm{AlC}_{2}$ (bulk) Courtesy of AZom.com [10].

Table 2. Comparison of the Avrami decomposition kinetics in MAX phases. Courtesy of AZom. com [10].

\begin{tabular}{lll}
\hline MAX Phase & Avrami Exponent (n) & Avrami Constant (k) (min \\
\hline $\mathrm{Ti}_{4} \mathrm{AlN}$ & $\mathbf{n}$ \\
$\mathrm{Ti}_{2} \mathrm{AlN}$ & 0.18 & 0.37 \\
$\mathrm{Ti}_{3} \mathrm{AlC}$ & 0.62 & 0.004 \\
$\mathrm{Ti}_{2} \mathrm{AlC}$ & 0.0023 & 0.93 \\
$\mathrm{Ti}_{3} \mathrm{SiC}_{2}$ & 0.11 & 0.608 \\
\hline
\end{tabular}

\section{Controlling Parameters on Decomposition or Degradation}

\subsection{Role of Vacuum Annealing}

The phase transitions in several $M A X$ phases and their relative phase abundances under high vacuum $\left(\sim 10^{-6}\right.$ torr) at various temperatures as revealed by in situ neutron diffraction are shown in Figure 2. A weight loss of $\sim 4 \%$ was observed for decomposed $\mathrm{Ti}_{3} \mathrm{SiC}_{2}$, which may be attributed to the release of gaseous $\mathrm{Ti}$ and $\mathrm{Si}$ by sublimation during the decomposition process. For $\mathrm{Ti}_{3} \mathrm{AlC}_{2}$, its decomposition into $\mathrm{TiC}$ and $\mathrm{Ti}_{2} \mathrm{AlC}$ as a lower order MAX phase or intermediate phase was observed at $\geq 1400{ }^{\circ} \mathrm{C}$. However, at higher temperatures, when compared to $\mathrm{TiC}$, a smaller growth rate for $\mathrm{Ti}_{2} \mathrm{AlC}$ may indicate that $\mathrm{Ti}_{2} \mathrm{AlC}$ experienced further decomposition into $\mathrm{TiC}$ via the sublimation of $\mathrm{Al}$, similar to decomposition of $\mathrm{Ti}_{3} \mathrm{SiC}_{2}$. In contrast to $\mathrm{Ti}_{3} \mathrm{AlC}_{2}$, no intermediate or lower order MAX phase was observed for the decomposition of $\mathrm{Ti}_{3} \mathrm{SiC}_{2}$. This difference can be attributed to the fact that $\mathrm{Ti}_{3} \mathrm{SiC}_{2}$ is the only stable ternary phase in the Ti-Si-C diagram. Figure $2 \mathrm{~d}$ shows the excellent stability of $\mathrm{Ti}_{2} \mathrm{AlN}$ at $1500{ }^{\circ} \mathrm{C}$ for up to $350 \mathrm{~min}$.

In general, a weight loss of up to $20 \%$ that was observed as a result of decomposition for all the MAX phases can be attributed to the release of gaseous Al by sublimation during the decomposition process because the vapor pressures of the $A$ elements exceed the ambient pressure of the furnace (i.e., $\leq 5 \times 10^{-5}$ torr) at $\geq 1500^{\circ} \mathrm{C}$. Since the vapor pressure of a substance increases non-linearly with temperature according to the Clausius-Clapeyron relation [29], the volatility of $A$ elements will increase with any incremental increase in temperature. 


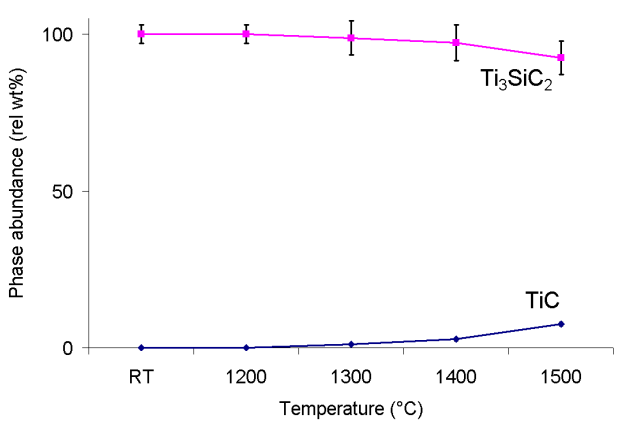

(a)

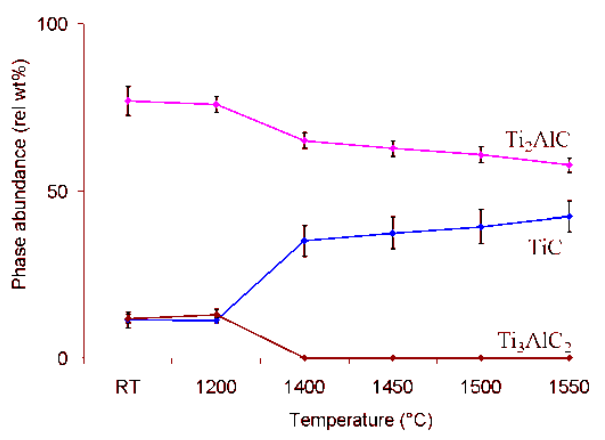

(c)

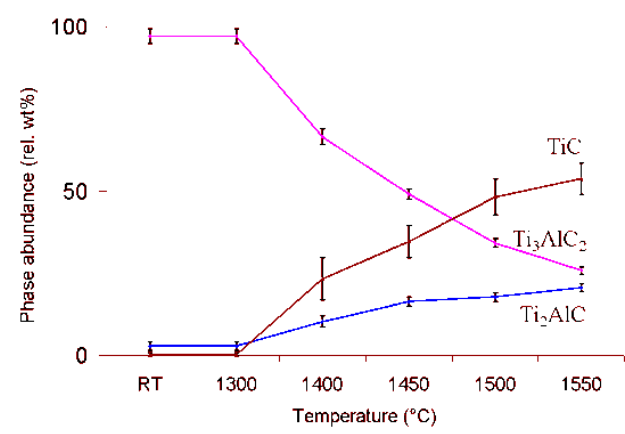

(b)

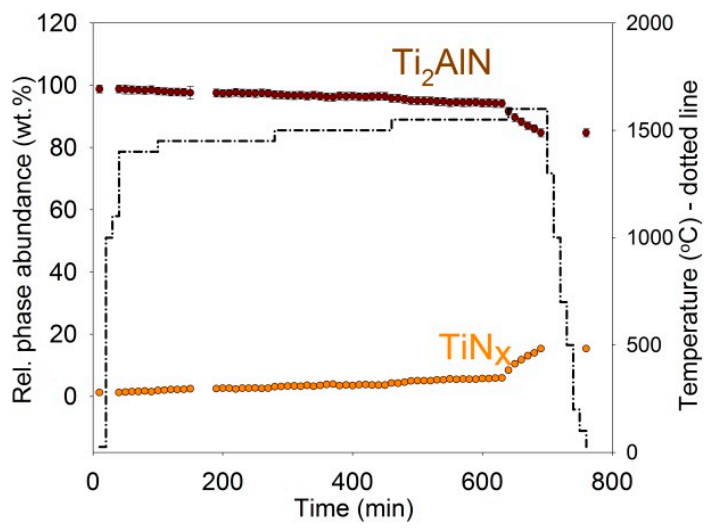

(d)

Figure 2. Phase abundance as a function of temperature for the decomposition of (a) $\mathrm{Ti}_{3} \mathrm{SiC}_{2}$, (b) $\mathrm{Ti}_{3} \mathrm{AlC}_{2}$, (c) $\mathrm{Ti}_{2} \mathrm{AlC}$, and (d) $\mathrm{Ti}_{2} \mathrm{AlN}$ in vacuum. Courtesy of AZom.com [10].

Our work on vacuum-induced decomposition of MAX phases has been verified by Zeng and co-workers [30] who investigated the phase evolution of $\mathrm{Ti}_{3} \mathrm{SiC}_{2}$ in vacuum furnace up to $1500{ }^{\circ} \mathrm{C}$. Decomposition of $\mathrm{Ti}_{3} \mathrm{SiC}_{2}$ via volatilization of $\mathrm{Si}$ was observed to commence at $1300{ }^{\circ} \mathrm{C}$ and became very severe at $1500{ }^{\circ} \mathrm{C}$, resulting in a porous microstructure. An intermediate phase $\mathrm{Ti}_{5} \mathrm{Si}_{3} \mathrm{C}_{x}$ was also observed to form between $1400{ }^{\circ} \mathrm{C}$ and $1450{ }^{\circ} \mathrm{C}$. Similarly, Zhang et al. [31] have investigated the erosion of $\mathrm{Ti}_{3} \mathrm{SiC}_{2}$ due to the high energy intensity and high temperature of a vacuum arc. This material was found to be unstable under vacuum and decomposed at the sample surface, forming $\mathrm{TiC}_{x}$, with the concomitant ejection of $\mathrm{Si}$ vapour into the vacuum chamber.

The thermal stability of $\mathrm{Ti}_{3} \mathrm{AlC}_{2} / \mathrm{Al}_{2} \mathrm{O}_{3}$ composites in high vacuum was investigated by Chen and co-workers [32]. On the sample surface, $\mathrm{Ti}_{3} \mathrm{AlC}_{2}$ was observed to decompose with the formation of $\mathrm{TiC}_{0.67}$ with gaseous $\mathrm{Al}$, followed by evaporation of Ti which resulted in the irregular morphology of non-stoichiometric $\mathrm{TiC}_{x}$. At the same time, the amount of $\mathrm{Al}_{2} \mathrm{O}_{3}$ particles decreased, with a prolonging of the dwell time. Finally, $\mathrm{Al}_{2} \mathrm{O}_{3}$ particles disappeared and a layer of non-stoichiometric $\mathrm{TiC}_{x}$ forms on the sample surface. It is worth mentioning here that the nature of vacuum experienced by the samples (i.e., static or dyanamic) is likely to play the ultimate role in the decomposition of MAX phases. A static vacuum environment is perceived to be a closed system in which any vaporized elements are likely to recondense and react with the host sample at elevated temperature. On the other hand, an environment of dynamic vacuum has less chance of recondensation but has a greater driving force for the continual vaporisation of the " $A$ " element, leading to rapid and extensive decomposition. In contrast to reported high thermal stability for bulk MAX-phase materials, their thin-film counterparts exhibited far inferior phase stability. For instance, Emmerlich and co-workers [33] synthesized $\mathrm{Ti}_{3} \mathrm{SiC}_{2}$ films using magnetron sputtering and these films were found to be stable during vacuum annealing at temperatures up to $\sim 1000{ }^{\circ} \mathrm{C}$ for $25 \mathrm{~h}$. However, annealing at $1100-1200{ }^{\circ} \mathrm{C}$ resulted in the rapid decomposition of $\mathrm{Ti}_{3} \mathrm{SiC}_{2}$ by $\mathrm{Si}$ out-diffusion along the basal planes via domain boundaries to the free 
surface with subsequent evaporation. Similarly, $\mathrm{Ti}_{2} \mathrm{AlN}$ thin films have been observed by Beckers and co-workers [34] to decompose as low as $\sim 800{ }^{\circ} \mathrm{C}$. The decomposition proceeded by outward $\mathrm{Al}$ diffusion and evaporation, followed by de-twinning of the as-formed $\mathrm{Ti}_{2} \mathrm{~N}$ atomic layers into cubic $\mathrm{TiN}_{x}$ and intermediate phases. The large difference in observed decomposition temperatures between bulk and thin-film $\mathrm{Ti}_{3} \mathrm{SiC}_{2}$ has been attributed to the difference in diffusion length scales involved and measurement sensitivity employed. These conflicting results suggest that the thermochemical stability of $\mathrm{Ti}_{3} \mathrm{SiC}_{2}$ and other MAX phases is still poorly understood, although their susceptibility to thermal decomposition is strongly influenced by factors such as vapour pressure, microstructure, furnace atmosphere and the nature of the vacuum (i.e., static or dynamic).

In another study, Zhang and co-workers [35] investigated the phase stability of single-crystalline $\mathrm{Ti}_{2} \mathrm{AlN}$ thin film in ultra-high vacuum using in situ by $\mathrm{X}$-ray photoelectron spectroscopy as a function of annealing temperature. The $\mathrm{Ti}_{2} \mathrm{AlN}$ thin-film was observed to be stable up to $600{ }^{\circ} \mathrm{C}$ but at $700{ }^{\circ} \mathrm{C}$, $\mathrm{Al}$ was preferentially desorbed from the surface and became nearly undetected at $900^{\circ} \mathrm{C}$ by XPS, and single-crystalline $\mathrm{Ti}_{2} \mathrm{AlN}$ with terrace morphology transformed into polycrystalline delta- $\mathrm{TiN}_{1-x}$ and $x i-\mathrm{TiN}_{0.75-y}$ phases with voids on the surface and reduced film thickness. The subsequent desorption of $\mathrm{Al}$ from the surface due to its high vapor pressure resulted in decreased $\mathrm{Al}$ composition, the void formation on the surface, and the decomposition of $\mathrm{Ti}_{2} \mathrm{AlN}$.

Using a combined cathodic arc/sputter technique, Wang and co-workers [36] were able to fabricate dense and higher stability $\mathrm{Ti}_{2} \mathrm{AlN}$ coatings. Following vacuum annealing at $1000{ }^{\circ} \mathrm{C}$ for $1 \mathrm{~h}$, these coatings were observed to remain intact with minimum degradation due to phase decomposition. This improved thermal stability is attributed to larger thickness and the denser structure, as well as the concomitant absence of defects (e.g., columnar grain boundaries, micro-cracks, and voids) which are the fast diffusion channels of $\mathrm{Al}$ to the surface under high vacuum conditions.

\subsection{Role of Argon Atmosphere}

As previous mentioned, Barsoum et al. [26] have shown that $\mathrm{Ti}_{3} \mathrm{SiC}_{2}$ is stable up to $1600{ }^{\circ} \mathrm{C}$ in argon for $4 \mathrm{~h}$. However, mixed results have been reported by others [28], such as where $\mathrm{Ti}_{3} \mathrm{SiC}_{2}$ was shown to be stable in a tungsten-heated furnace for $10 \mathrm{~h}$ at $1600{ }^{\circ} \mathrm{C}$ in argon, but dissociated to $\mathrm{TiC}_{x}$ when a graphite heater was used. In our previous work on decomposition of $\mathrm{Ti}_{3} \mathrm{SiC}_{2}$ at elevated temperatures in an argon atmosphere [14], we showed that this material remained quite stable at $1000{ }^{\circ} \mathrm{C}$ and that the phase concentrations of $\mathrm{Ti}_{3} \mathrm{SiC}_{2}$ and $\mathrm{TiC}$ impurity remained unchanged. However, at $1100{ }^{\circ} \mathrm{C}, \mathrm{Ti}_{3} \mathrm{SiC}_{2}$ was observed to decompose and form additional TiC. The thermal dissociation process was slow below $1200{ }^{\circ} \mathrm{C}$, but the process became quite rapid from 1250 to $1400{ }^{\circ} \mathrm{C}$. A small amount of transient phase $\mathrm{Ti}_{5} \mathrm{Si}_{3} \mathrm{C}_{x}$ was observed to form from 20 to $1400{ }^{\circ} \mathrm{C}$. This phase is believed to form during the initial decomposition stage of $\mathrm{Ti}_{3} \mathrm{SiC}_{2}$ and converts to the stable $\mathrm{TiC}$ at elevated temperature. The existence of this transient phase at $1400-1450{ }^{\circ} \mathrm{C}$ has also been reported by Zeng et al. [30] in their study on phase decomposition of $\mathrm{Ti}_{3} \mathrm{SiC}_{2}$ under vacuum. It should be emphasized that an impurity such as TiC is unlikely to impart significant influence on phase decomposition because the process of decomposition involves primarily, if not exclusively, vaporization of the " $A$ element".

A similar phenomenon of MAX phase decomposition in argon has been reported by other investigators. The thermal stability of $\mathrm{Cr}_{2} \mathrm{AlC}$ in argon has been investigated by Xiao and co-workers [37]. According to these researchers, the produced $\mathrm{Cr}_{2} \mathrm{AlC}$ ceramic was stable up to $1500{ }^{\circ} \mathrm{C}$ in an $\mathrm{Ar}$ atmosphere, but decomposed into $\mathrm{Al}_{8} \mathrm{Cr}_{5}$ and $\mathrm{Cr}_{23} \mathrm{C}_{6}$ above $1500{ }^{\circ} \mathrm{C}$. In another study on nanolaminated ternary boride $\mathrm{Fe}_{2} \mathrm{AlB}_{2}$ [38], the thermal stability of $\mathrm{Fe}_{2} \mathrm{AlB}_{2}$ at temperatures up to $1300{ }^{\circ} \mathrm{C}$ in $\mathrm{Ar}$ atmosphere was studied. It was observed that $\mathrm{Fe}_{2} \mathrm{AlB}_{2}$ intensively decomposed at $1236^{\circ} \mathrm{C}$ in Ar atmosphere. In a separate study, Zhang and co-workers [39] investigated the thermal stability of bulk $\mathrm{Zr}_{2} \mathrm{Al}_{4} \mathrm{C}_{5}$ at elevated temperatures $\left(20-2000{ }^{\circ} \mathrm{C}\right)$ under flowing argon. This material was observed to decompose initially at $1900^{\circ} \mathrm{C}$ and became severely decomposed at $2000{ }^{\circ} \mathrm{C}$, forming 
$\mathrm{ZrC}_{1-x}$ and $\mathrm{Al}_{4} \mathrm{C}_{3}$ on the surface. Similar to MAX phases, the mechanism of decomposition involved sublimation of $\mathrm{Al}$ and weaker covalent bonds between $\mathrm{ZrC}$ slabs and $\mathrm{Al}_{4} \mathrm{C}_{3}$ layers.

The thermal stability of $\mathrm{Ti}_{3} \mathrm{AlC}_{2}$ at $1250-1400{ }^{\circ} \mathrm{C}$ in a $10 \% \mathrm{CO}$-Ar atmosphere has been investigated by Gai et al. [40]. Decomposition of $\mathrm{Ti}_{3} \mathrm{AlC}_{2}$ was observed to commence at $1250{ }^{\circ} \mathrm{C}$ and a mixture layer of $\mathrm{Ti}(\mathrm{O}, \mathrm{C})$ and $\mathrm{Al}_{2} \mathrm{O}_{3}$ formed at $1250-1300{ }^{\circ} \mathrm{C}$. Thermal stability of MAX-phase coatings in argon atmosphere has also been investigated by several researchers. Using magnetron sputtering from $\mathrm{Cr}$-Al-C composite targets at room temperature, $\mathrm{Li}$ and co-workers [41] prepared polycrystalline $\mathrm{Cr}_{2} \mathrm{AlC}$ coatings on a M38G superalloy. No phase decomposition was observed during subsequent annealing of these coatings in argon at $620^{\circ} \mathrm{C}$ for up to $20 \mathrm{~h}$. However, when annealing in argon was increased to $1100{ }^{\circ} \mathrm{C}$, Smialek et al. [42] observed an interfacial reaction between $\mathrm{Cr}_{2} \mathrm{AlC}$ and an Ni-based LSHR alloy with the concomitant formation of an Al-depletion zone of $\mathrm{Cr}_{7} \mathrm{C}_{3}$.

As with argon, the effect of hydrogen atmosphere on the high-temperature $\left(1200-1400{ }^{\circ} \mathrm{C}\right)$ thermal stability of $\mathrm{Ti}_{3} \mathrm{SiC}_{2}$ was investigated by Chen and co-workers [43]. However, in this case the decomposed product was not $\mathrm{TiC}_{x}$. Instead, a dense $\mathrm{TiSi}_{2}$ layer formed on the sample surface at $1200{ }^{\circ} \mathrm{C}$. The formation this $\mathrm{TiSi}_{2}$ layer caused the volume expansion and subsequently spalled off the surface at $1300-1400{ }^{\circ} \mathrm{C}$. It remains a mystery why in a hydrogen atmosphere $\mathrm{Ti}_{3} \mathrm{SiC}_{2}$ decomposes to $\mathrm{TiSi}_{2}$ rather than the commonly observed $\mathrm{TiC}_{x}$.

\subsection{Role of Pore Microstructure}

It is well known that $A$ elements such as $\mathrm{Si}$ and $\mathrm{Al}$ have high vapour pressure and become volatile at elevated temperatures. Thus, at the temperatures of well over $1500{ }^{\circ} \mathrm{C}$ used in this study, both $\mathrm{Al}$ and $\mathrm{Si}$ should become volatile and sublime readily and continuously in a dynamic environment of high vacuum. When the vapor pressure becomes sufficient to overcome ambient pressure in the vacuum furnace, bubbles will form inside the bulk of the substance and eventually appear as voids on the surface of the decomposed MAX phase. The evidence of surface void formation can be clearly discerned from the porous surface damage of decomposed $\mathrm{Ti}_{2} \mathrm{AlN}$ and $\mathrm{Ti}_{4} \mathrm{AlN}_{3}$ (Figure 3). These void formations are evident from the scanning electron micrographs of decomposed MAX phases shown in Figure 1. Si has a lower vapour pressure than $\mathrm{Al}$, and this explains why $\mathrm{Ti}_{3} \mathrm{SiC}_{2}$ is more resistant to decomposition than $\mathrm{Ti}_{3} \mathrm{AlC}_{2}$ or $\mathrm{Ti}_{2} \mathrm{AlN}$. In all cases, the kinetics of the decomposition process are driven mainly by a highly restricted out-diffusion and sublimation of high vapour pressure $A$ element (e.g., $\mathrm{Al}$ and $\mathrm{Si}$ ) from the bulk to the surface of the sample and into the vacuum, i.e.,

$$
\begin{gathered}
M_{n+1} A X_{n} \rightarrow M_{n+1} X_{n}+A \\
M_{n+1} X_{n} \rightarrow(n+1) M X_{n /(n+1)}
\end{gathered}
$$

As previously mentioned, research conducted in our laboratories shows that activation energies of phase decomposition are strongly influenced by the pore microstructures of decomposed material. A decomposed surface layer with very fine pores $(<1.0 \mu \mathrm{m})$ has a ability to exert an increasing resistance to the sublimation process as the temperature increases. However, a more porous decomposed layer with coarser pores $(>2.0 \mu \mathrm{m})$ would enable the sublimation of $\mathrm{Al}$ or $\mathrm{Si}$ to progress with minimum resistance, thus resulting in an increasing rate of decomposition with temperature. In short, pore size plays a critical role in controlling the kinetics of decomposition in MAX phases. Thus, the ability to manipulate pore microstructure either through densification to reduce pore size or engineering of pore free microstructures will allow the process of decomposition in MAX phases to be minimized or arrested. 


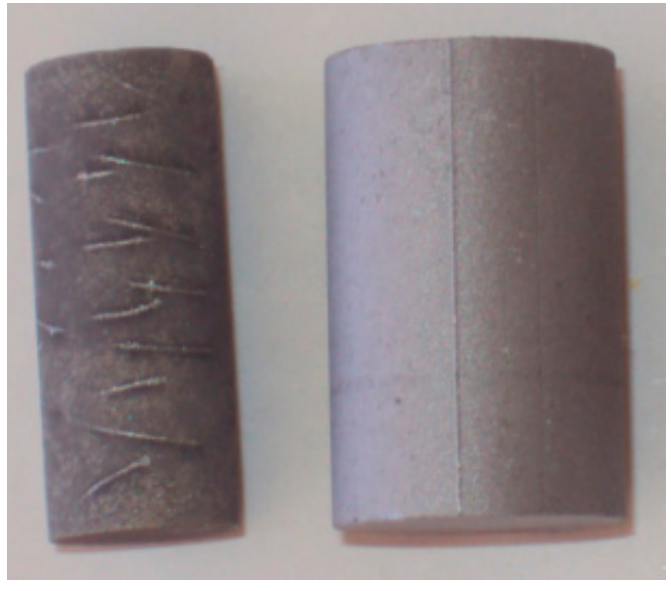

(a)

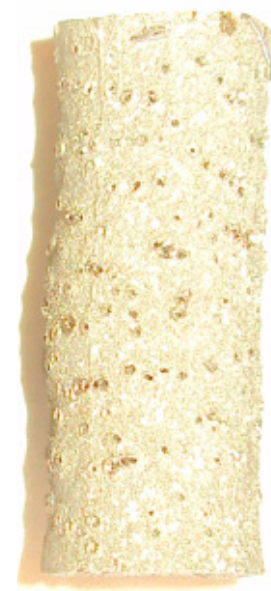

(b)

Figure 3. Surface conditions of $\mathrm{Ti}_{4} \mathrm{AlN}_{3}$ (left) and $\mathrm{Ti}_{2} \mathrm{AlN}$ (right) before (a) and after (b) thermal decomposition in vacuum.

\subsection{Role of High Pressure}

As mentioned above, a vacuum can provide a conducive environment for the vaporization of "A elements" (e.g., Si or Al) in MAX phases, leading to their subsequent decomposition. It would thus follow that the reverse (i.e., an increasing pressure) would provide hindrance to the escape of the "A elements" and hence improve the thermal stability at elevated temperature. However, this hypothesis has, surprisingly, been proven to be incorrect. For instance, the effect of high pressure (3-5 GPa) on the high-temperature phase stability of $\mathrm{Ti}_{3} \mathrm{SiC}_{2}$ has been investigated by Qin and He [44]. Similarly to high-vacuum annealing, which tends to destabilize MAX phases, the decomposition temperature of $\mathrm{Ti}_{3} \mathrm{SiC}_{2}$ decreases quickly with increasing pressure, and the low temperature limits of phase segregation of the sample $\mathrm{Ti}_{3} \mathrm{SiC}_{2}$ lie between $1100{ }^{\circ} \mathrm{C}$ and $1000{ }^{\circ} \mathrm{C}, 1000{ }^{\circ} \mathrm{C}$ and $900{ }^{\circ} \mathrm{C}$, and $900^{\circ} \mathrm{C}$ and $800^{\circ} \mathrm{C}$, under high pressures of 3, 4, and $5 \mathrm{GPa}$, respectively. The decomposed products observed are $\mathrm{TiC}, \mathrm{SiC}$, and $\mathrm{TiSi}_{x}$. The process of decomposition involved the outward diffusion of $\mathrm{Si}$, followed by shrinking of material through relaxation of the $\mathrm{Ti}_{3} \mathrm{C}_{2}$ slabs, is similar to those observed in $\mathrm{Ti}_{3} \mathrm{SiC}_{2}$ thin film phase decomposition [24]. The released $\mathrm{Si}$ then reacts with $\mathrm{Ti}_{3} \mathrm{C}_{2}$ or $\mathrm{TiC}_{0.67}$ to form $\mathrm{TiC}, \mathrm{SiC}$, and $\mathrm{TiSi}_{x}$ at high pressure-temperature conditions. Similarly, $\mathrm{Ti}_{2} \mathrm{AlC}_{\mathrm{C}}$ is also unstable when the temperature is above $900{ }^{\circ} \mathrm{C}$ under $5 \mathrm{GPa}$ pressure, and the decomposition temperature decreases with increasing pressure. The phase decomposition temperature of $\mathrm{Ti}_{2} \mathrm{AlC}$ detected was $890 \pm 10^{\circ} \mathrm{C}$ at $5 \mathrm{GPa}$ and $1030 \pm 10^{\circ} \mathrm{C}$ at $4 \mathrm{GPa}[45,46]$. However, $\mathrm{Ti}_{2} \mathrm{AlN}$ has been observed to be more stable than $\mathrm{Ti}_{2} \mathrm{AlC}$ under similar high pressure-temperature conditions. An and co-workers [47] investigated the stability of $\mathrm{Ti}_{2} \mathrm{AlN}$ at $5 \mathrm{GPa}$ and different temperatures of $700-1600{ }^{\circ} \mathrm{C}$. Under a pressure of $5 \mathrm{GPa}$ for $20 \mathrm{~min}, \mathrm{Ti}_{2} \mathrm{AlN}$ was observed to maintain stability at high temperatures up to $1400{ }^{\circ} \mathrm{C}$ but decomposed into TiN and TiAl directly at $1500{ }^{\circ} \mathrm{C}$. It should be noted that the effect of pressure on the thermal stability of MAX phases at elevated temperature has so far been exclusively investigated by only one group of researchers (i.e., He and co-workers) based in a Thai university. This important claim warrants further work and it needs to be independently verified by other researchers from various countries.

\subsection{Role of Ion-Irradiation}

Before MAX phases can be seriously considered for use by design engineers as a potential structural nuclear material for the fourth generation of reactors and future fusion reactors, their damage tolerance to irradiation requires careful investigations. So far, numerous studies have been 
conducted in this topic but mixed results have been obtained. An excellent work has recently been conducted by Tallman and co-workers $[7,48,49]$ to investigate the effects of neutron irradiation on $\mathrm{Ti}_{3} \mathrm{AlC}_{2}, \mathrm{Ti}_{2} \mathrm{AlC}, \mathrm{Ti}_{3} \mathrm{SiC}_{2}, \mathrm{Ti}_{4} \mathrm{AlN}_{3}$, and $\mathrm{Ti}_{2} \mathrm{AlN}$. Following irradiation, these samples were observed to decompose to either $\mathrm{TiC}$ or $\mathrm{TiN}$ together with formation of defects such as dislocation loops, stacking faults, cavities, and even microcraking. Swelling and microcracking were also observed by Ang et al. [50,51] for $\mathrm{Ti}_{3} \mathrm{AlC}_{2}-\mathrm{Ti}_{5} \mathrm{Al}_{2} \mathrm{C}_{3}$ materials irradiated with neutrons, with subsequent reduction in their flexural strengths by up to $90 \%$. Ion irradiation has also been observed to induce phase transition and decomposition of MAX phases. Qi and co-workers [52] irradiated $\mathrm{Ti}_{3} \mathrm{SiC}_{2}$ with $700 \mathrm{keV}$ $\mathrm{C}$ ions over a range of fluences and sample temperatures. Irradiation at temperatures from room temperature to $270{ }^{\circ} \mathrm{C}$ resulted in decomposition of $\mathrm{Ti}_{3} \mathrm{SiC}_{2}$ to $\mathrm{TiC}$. A similar phenomenon was observed for $\mathrm{Ti}_{3} \mathrm{SiC}_{2}$ when it was bombarded with $\mathrm{MeV}$ iodine [53], resulting in precipitation of $\mathrm{TiC}_{x}$ due to surface decomposition.

\subsection{Role of Miscellaneous Factors}

This overview will not be comprehensive without mentioning other factors that also play a role in the degradation of MAX phases. In these materials, the $M_{n+1} X_{n}$ layers are generally quite stable but the " $A$ " layers are not, because the latter are weakly bound and susceptible to selective reaction with their environment by diffusing out of the basal planes. In general, the solubility of the $A$ elements plays a deciding role in controlling the propensity of the reaction between max phases and various substances such as molten metals or salts as well as common bases and acids [7].

For instance, Bentzel et al. [54] investigated the interactions between $\mathrm{SiC}$ and pyrolytic carbon (PG) with $\mathrm{Ti}_{2} \mathrm{AlC}, \mathrm{Ti}_{3} \mathrm{AlC}_{2}, \mathrm{Ti}_{3} \mathrm{SiC}_{2}$, and $\mathrm{Cr}_{2} \mathrm{AlC}$. No reaction was observed between $\mathrm{SiC}$ and $\mathrm{Ti}_{3} \mathrm{SiC}_{2}$ or $\mathrm{Cr}_{2} \mathrm{AlC}$ after $30 \mathrm{~h}$ at $1300{ }^{\circ} \mathrm{C}$. Additionally, no reaction was apparent between $\mathrm{PG}$ and $\mathrm{Ti}_{3} \mathrm{SiC}_{2}$. However, when heated under vacuum, the $\mathrm{Ti}_{3} \mathrm{AlC}_{2} / \mathrm{SiC}$ and $\mathrm{Ti}_{3} \mathrm{AlC}_{2} / \mathrm{PG}$ diffusion couples resulted in TiC layers that were $\sim 50 \mu \mathrm{m}$ and $\sim 100 \mu \mathrm{m}$ thick, respectively. Similarly, an interfacial layer $(\sim 10 \mu \mathrm{m})$ of $\mathrm{Cr}_{3} \mathrm{C}_{2}$ and $\mathrm{Cr}_{7} \mathrm{C}_{3}$ was seen to form on the $\mathrm{Cr}_{2} \mathrm{AlC} / \mathrm{PG}$ diffusion couple. Chiker and co-workers investigated the infiltration behavior of $\mathrm{Ti}$ and $\mathrm{Cu}$ fillers into a $\mathrm{Ti}_{2} \mathrm{AlC} / \mathrm{Ti}_{3} \mathrm{AlC}_{2}$ composite using a TIG-brazing process [55]. They observed that $\mathrm{Ti}_{2} \mathrm{AlC} / \mathrm{Ti}_{3} \mathrm{AlC}_{2}$ decomposed into $\mathrm{TiC}_{x}$ and $\mathrm{Ti}_{3} \mathrm{AlC}$ when it came into contact with molten $\mathrm{Ti}$. The $\mathrm{Ti}_{3} \mathrm{AlC}_{2}$ phase decomposed completely in the presence of $\mathrm{Cu}$ or Ti filler-materials. On the other hand, Liu and co-workers [56] took advantage of partial decomposition in fabricating $\mathrm{Ag} / \mathrm{Ti}_{3} \mathrm{AlC}_{2}$ composites with enhanced mechanical properties through the formation of $\mathrm{Ag}(\mathrm{Al})$ solid solution in the interfacial zone between $\mathrm{Ag}$ and $\mathrm{Ti}_{3} \mathrm{AlC}_{2}$. A similar concept was utilized by Septiadi et al. [57] in joining $\mathrm{SiC}_{\mathrm{f}} / \mathrm{SiC}$ composites with thin tapes of $\mathrm{Ti}_{3} \mathrm{AlC}_{2}$ or $\mathrm{Ti}_{3} \mathrm{SiC}_{2}$. Again, strong joining was successfully accomplished through solid-state diffusion bonding courtesy of partial decomposition of the tapes. Lastly, the prized outcome of utilizing selective removal of the " $A$ " element from MAX phases through chemical solution etching is the discovery of the sensational two-dimensional, ordered, double transition metals carbides, or Mxenes [58].

\section{Concluding Remarks}

The rediscovery of MAX phases by Barsoum and co-workers in the 1990s caused a sensation and research activities on these materials exploded in the late 1990s and early 2000s, particularly from researchers in China. However, this flurry of research activities, especially on synthesis and properties, has started to wane in recent years, partly due to the inability to find suitable applications and to commercialize them because of cost. The issue of thermal stability described above may have also played a part. Before MAX phases can be widely used in harsh and extreme environments such as aircraft engine components, rocket engine nozzles, or structural materials for Generation IV nuclear reactors, the issues pertaining to their susceptibility to thermal decomposition need to be fully addressed.

Ironically, it is the understanding of phase decomposition via de-intercalation of these materials that has laid the foundation or catalyst for the eventual discovery of Mxenes. The glory days of MAX 
phases are now well and truly over and the excitement is now focused on Mxenes. Nevertheless, it is heartening to notice that very active research activities on MAX phases, especially on damage tolerance to irradiations, are still going on with a view to utilizing these materials for high temperature nuclear applications.

Funding: This research was funded by the Australian Research Council (grant numbers DP0664586, LX0774743, and LE0882725), and grants P329, P606, P1431, and MI1488 were funded by AINSE and ISIS.

Acknowledgments: I am grateful to J.-P. Palmquist and Z.M. Sun for providing the samples. I thank my former PhD students (W.K. Pang and Z. Oo) for experimental work and data analysis, and my colleague E/B. O'Connor for guidance on Rietveld analysis. Finally, I thank R. Smith (ISIS) and both V. Peterson and S. Kennedy of the Bragg Institute at ANSTO for technical assistance in data collection.

Conflicts of Interest: The author declares no conflict of interest.

\section{References}

1. Barsoum, M.W. The $M_{n+1} A X_{n}$ phases: A new class of solids: Thermodynamically stable nanolaminates. Prog. Solid State Chem. 2000, 28, 201-281. [CrossRef]

2. Zhang, H.B.; Bao, Y.W.; Zhou, Y.C. Current status in layered ternary carbides: A review. J. Mater. Sci. Technol. 2009, 25, 1-38.

3. Sun, Z.M. Progress in research and development on MAX phases. Int. Mater. Rev. 2011, 56, 1-43. [CrossRef]

4. Barsoum, M.W. El-Raghy, The MAX phases: Unique new carbide and nitride materials. Am. Sci. 2001, 89, 334-343. [CrossRef]

5. Low, I.M.; Lee, S.K.; Barsoum, M.W.; Lawn, B.R. Contact Hertzian response of $\mathrm{Ti}_{3} \mathrm{SiC}_{2}$ ceramics. J. Am. Ceram. Soc. 1998, 81, 225. [CrossRef]

6. Low, I.M. Vickers contact damage of micro-layered $\mathrm{Ti}_{3} \mathrm{SiC}_{2}$. J. Eur. Ceram. Soc. 1998, 18, 709-713. [CrossRef]

7. Tallman, D.J.; Hoffman, E.N.; Caspi, E.N.; Garcia-Diaz, B.L.; Kohse, G.; Sindelar, R.L.; Barsoum, M.W. Effect of neutron irradiation on select MAX phases. Acta Mater. 2015, 85, 132-143. [CrossRef]

8. Zhang, L.; Qi, Q.; Shi, L.Q.; O'Connor, D.J.; King, B.V.; Kisi, E.H.; Venkatachalam, D.K. Damage tolerance of $\mathrm{Ti}_{3} \mathrm{SiC}_{2}$ to high energy iodine irradiation. Appl. Surf. Sci. 2012, 258, 6281-6287. [CrossRef]

9. Whittle, K.R.; Blackford, M.G.; Aughterson, R.D.; Moricca, S.; Lumpkin, G.R.; Riley, D.P.; Zaluzec, N.J. Radiation tolerance of $M_{n+1} A X_{n}$ phases, $\mathrm{Ti}_{3} \mathrm{AlC}_{2}$ and $\mathrm{Ti}_{3} \mathrm{SiC}_{2}$. Acta Mater. 2010, 58, 4362-4368. [CrossRef]

10. Low, I.M. Thermal Decomposition of MAX Phases. Available online: https://www.azom.com/article.aspx? ArticleID=6711 (accessed on 1 February 2019).

11. Low, I.M.; Wren, E.; Prince, K.E.; Anatacio, A. Characterisation of phase relations and properties in air-oxidised $\mathrm{Ti}_{3} \mathrm{SiC}_{2}$. Mater. Sci. Eng. A 2007, 466, 140-147. [CrossRef]

12. Low, I.M.; Pang, W.K. Kinetics of decomposition in MAX phases at elevated temperature. Mater. Aust. Mag. 2011, 6, 33-35.

13. Low, I.M.; Oo, Z.; Prince, K.E. Effect of vacuum annealing on the phase stability of $\mathrm{Ti}_{3} \mathrm{SiC}_{2}$. J. Am. Ceram. Soc. 2007, 90, 2610-2615. [CrossRef]

14. Oo, Z.; Low, I.M.; O'Connor, B.H. Dynamic study of the thermal stability of impure $\mathrm{Ti}_{3} \mathrm{SiC}_{2}$ in argon and air by neutron diffraction. Physica B 2006, 385-386, 499-501. [CrossRef]

15. Pang, W.K.; Low, I.M.; O'Connor, B.H.; Studer, A.J.; Peterson, V.K.; Palmquist, J.P. Diffraction study of high-temperature thermal dissociation of Maxthal $\mathrm{Ti}_{2} \mathrm{AlC}$ in vacuum. J. Alloys Compd. 2010, 509, 172-176. [CrossRef]

16. Pang, W.K.; Low, I.M.; O'Connor, B.H.; Studer, A.J.; Peterson, V.K.; Sun, Z.M.; Palmquist, J.-P. Comparison of thermal stability in MAX 211 and 312 phases. J. Phys. Conf. Ser. 2010, 251, 012025. [CrossRef]

17. Pang, W.K.; Low, I.M. Diffraction study of thermal dissociation in the ternary Ti-Al-C system. J. Aust. Ceram. Soc. 2009, 45, 39-43.

18. Pang, W.K.; Low, I.M.; Sun, Z.M. In-situ high-temperature diffraction study of thermal dissociation of $\mathrm{Ti}_{3} \mathrm{AlC}_{2}$ in vacuum. J. Am. Ceram. Soc. 2010, 93, 2871-2876. [CrossRef]

19. Low, I.M.; Pang, W.K.; Kennedy, S.J.; Smith, R.I. High-temperature thermal stability of $\mathrm{Ti}_{2} \mathrm{AlN}_{\text {and }} \mathrm{Ti}_{4} \mathrm{AlN}_{3}$ : A comparative diffraction study. J. Eur. Ceram. Soc. 2011, 31, 159-166. [CrossRef]

20. Pang, W.K.; Low, I.M.; Kennedy, S.J.; Smith, R.I. Diffraction study on the thermal stability of $\mathrm{Ti}_{2} \mathrm{AlN}$ at 1500-1800 ${ }^{\circ} \mathrm{C}$ in vacuum. Mater. Sci. Eng. A 2010, 528, 137-142. [CrossRef] 
21. Zhang, H.; Zhou, Y.; Bao, Y.; Li, M. Titanium silicon carbide pest induced by nitridation. J. Am. Ceram. Soc. 2008, 91, 494-499. [CrossRef]

22. Feng, A.; Orling, T.; Munir, Z.A. Field-activated pressure-assisted combustion synthesis of polycrystalline $\mathrm{Ti}_{3} \mathrm{SiC}_{2}$. J. Mater. Res. 1999, 14, 925-939. [CrossRef]

23. Gao, N.F.; Miyamoto, Y.; Zhang, D. On physical and thermochemical properties of high-purity $\mathrm{Ti}_{3} \mathrm{SiC}_{2}$. Mater. Lett. 2002, 55, 61-66. [CrossRef]

24. Emmerlich, J.; Music, D.; Eklund, P.; Wilhelmsson, O.; Jansson, U.; Schneider, J.M.; Högberg, H.; Hultman, L. Thermal stability of $\mathrm{Ti}_{3} \mathrm{SiC}_{2}$ thin films. Acta Mater. 2007, 55, 1479-1488. [CrossRef]

25. Barsoum, M.W. MAX Phases: Properties of Machinable Ternary Carbides and Nitrides; John Wiley \& Sons: New York, NY, USA, 2013.

26. Barsoum, M.W.; El-Raghy, T. Synthesis and characterization of remarkable ceramic: $\mathrm{Ti}_{3} \mathrm{SiC}_{2}$. J. Am. Ceram. Soc. 1996, 79, 1953-1956. [CrossRef]

27. Tzenov, N.; Barsoum, M.W.; El-Raghy, T. Influence of small amounts of Fe and V on the synthesis and stability of $\mathrm{Ti}_{3} \mathrm{SiC}_{2}$. J. Eur. Ceram. Soc. 2000, 20, 801-806. [CrossRef]

28. Radakrishnan, R.; Williams, J.J.; Akinc, M. Synthesis and high-temperature stability of $\mathrm{Ti}_{3} \mathrm{SiC}_{2}$. J. Alloys Compd. 1999, 285, 85-88. [CrossRef]

29. Callen, H.B. Thermodynamics and an Introduction to Thermostatistics; Wiley: New York, NY, USA, 1985.

30. Zeng, J.; Ren, S.; Lu, J. Phase evolution of $\mathrm{Ti}_{3} \mathrm{SiC}_{2}$ annealing in vacuum at elevated temperatures. Int. J. Appl. Ceram. Technol. 2013, 10, 527-539. [CrossRef]

31. Zhang, P.; Ngai, T.L.; Xie, H.; Li, Y. Erosion behaviour of a $\mathrm{Ti}_{3} \mathrm{SiC}_{2}$ cathode under low-current vacuum arc. J. Phys. D Appl. Phys. 2013, 46, 395202. [CrossRef]

32. Chen, J.X.; Zhou, Y.C.; Zhang, H.B.; Wan, D.T.; Liu, M.Y. Thermal stability of $\mathrm{Ti}_{3} \mathrm{AlC}_{2} / \mathrm{Al}_{2} \mathrm{O}_{3}$ Composites in High Vacuum. Mater. Chem. Phys. 2007, 104, 109-122. [CrossRef]

33. Eklund, P.; Beckers, M.; Jansson, U.; Högberg, H.; Hultman, L. The $M_{n_{+1}} A X_{n}$ phases: Materials science and thin-film processing. Thin Solid Films 2010, 518, 1851-1878. [CrossRef]

34. Beckers, M.; Schell, N.; Martins, R.M.S.; Mucklich, A.; Moller, W. Phase stability of epitaxially grown $\mathrm{Ti}_{2} \mathrm{AlN}$ thin films. Appl. Phys. Lett. 2006, 89, 074101. [CrossRef]

35. Zhang, Z.; Jin, H.; Chai, J.; Shen, L.; Seng, H.L.; Pan, J.; Wong, L.M.; Sullivan, M.B.; Wang, S.J. Desorption of $\mathrm{Al}$ and phase transformation of $\mathrm{Ti}_{2} \mathrm{AlN}$ MAX thin film upon annealing in ultra-high-vacuum. J. Phys. Chem. C 2014, 118, 20927-20939. [CrossRef]

36. Wang, Z.; Liu, J.; Wang, L.; Li, X.; Ke, P.; Wang, A. Dense and high-stability Ti 2 AlN MAX phase coatings prepared by the combined cathodic arc/sputter technique. App. Surf. Sci. 2017, 396, 1435-1442. [CrossRef]

37. Xiao, L.-O.; Li, S.-B.; Song, G.; Sloof, W.G. Synthesis and thermal stability of $\mathrm{Cr}_{2}$ AlC. J. Eur. Ceram. Soc. 2011, 31, 1497-1502. [CrossRef]

38. Liu, J.; Li, S.-B.; Yao, B.; Zhang, J.; Lu, X.; Zhou, Y. Thermal stability and thermal shock resistance of Fe $\mathrm{AlB}_{2}$. Ceram. Int. 2018, 44, 16035-16039. [CrossRef]

39. Zhang, R.; Chen, G.; Pei, Y.; Fang, D. Thermal stability of bulk $\mathrm{Zr}_{2} \mathrm{Al}_{4} \mathrm{C}_{5}$ ceramic at elevated temperatures. Int. J. Refract. Met. Hard Mater. 2012, 30, 102-106. [CrossRef]

40. Gai, J.; Chen, J.; Li, M. Thermal stability of $\mathrm{Ti}_{3} \mathrm{AlC}_{2}$ in Ar-10vol.\%CO atmosphere. J. Eur. Ceram. Soc. 2016, 36, 2837-2841. [CrossRef]

41. Li, Y.; Zhao, G.; Qian, Y.; Xu, J.; Li, M. Deposition of phase-pure $\mathrm{Cr}_{2} \mathrm{AlC}$ coating by DC magnetron sputtering and post annealing using $\mathrm{Cr}-\mathrm{Al}-\mathrm{C}$ targets with controlled elemental composition but different phase compositions. J. Mater. Sci. Technol. 2018, 34, 466-471. [CrossRef]

42. Smialek, J.L.; Garg, A. Interfacial reactions of a MAX phase/superalloy hybrid. Surf. Interface Anal. 2015, 47, 844-853. [CrossRef]

43. Chen, C.; Li, F.Z.; Xu, C.H.; Zhang, H.-B.; Peng, S.M. High-temperature hydrogenation behaviour of bulk titanium silicon carbide. Adv. Appl. Ceram. 2016, 115, 288-293. [CrossRef]

44. Qin, J.; He, D. Phase stability of $\mathrm{Ti}_{3} \mathrm{SiC}_{2}$ at high pressure and high temperature. Ceram. Int. 2013, 39, 9361-9367. [CrossRef]

45. Qin, J.; He, D.; Lei, L.; An, P.; Fang, L.; Li, Y.; Wang, F.; Kou, Z. Differential thermal analysis study of phase segregation of $\mathrm{Ti}_{2} \mathrm{AlC}$ under high pressure and high temperature. J. Alloys Compd. 2009, 476, L8-L10. [CrossRef] 
46. Qin, J.; He, D.; Chen, C.; Wang, J.; Hu, J.; Yang, B. Phase segregation of titanium-aluminium carbide (Ti $\left.{ }_{2} \mathrm{AlC}\right)$ at high pressure and high temperature. J. Alloys Compd. 2008, 462, L24-L27. [CrossRef]

47. An, P.; He, Z.; Qin, J.; Li, Z.; Li, Y.; Kou, Z.; He, D. Stability of titanium-aluminium nitride (Ti $\left.{ }_{2} \mathrm{AlN}\right)$ at high pressure and high temperatures. J. Wuhan Univ. Technol. Mater. Sci. Ed. 2011, 26, 914-919. [CrossRef]

48. Tallman, D.J.; He, L.; Garcia-Diaz, B.L.; Hoffman, E.N.; Kohse, G.; Sindelar, R.L.; Barsoum, M.W. Effect of neutron irradiation on defect evolution in $\mathrm{Ti}_{3} \mathrm{SiC}_{2}$ and $\mathrm{Ti}_{2} \mathrm{AlC}$. J. Nucl. Mater. 2016, 468, 194-206. [CrossRef]

49. Tallman, D.J.; He, L.; Gan, J.; Caspi, E.N.; Hoffman, E.N.; Barsoum, M.W. Effects of neutron irradiation of $\mathrm{Ti}_{3} \mathrm{SiC}_{2}$ and $\mathrm{Ti}_{3} \mathrm{AlC}_{2}$ in the $121-1085^{\circ} \mathrm{C}$ temperature range. J. Nucl. Mater. 2017, 484, 120-134. [CrossRef]

50. Ang, C.; Silva, C.; Shih, C.; Koyanagi, T.; Katoh, Y.; Zinkle, S.J. Anisotropic swelling and microcracking of neutron irradiated $\mathrm{Ti}_{3} \mathrm{AlC}_{2}-\mathrm{Ti}_{5} \mathrm{Al}_{2} \mathrm{C}_{3}$ materials. Scr. Mater. 2016, 114, 74-78. [CrossRef]

51. Ang, C.; Parish, C.M.; Shih, C.; Silva, C.; Katoh, Y. Microstructure and mechanical properties of titanium aluminum carbides neutron irradiated at $400-700{ }^{\circ}$ C. J. Eur. Ceram. Soc. 2017, 37, 2353-2363. [CrossRef]

52. Qi, Q.; Cheng, G.J.; Shi, L.Q.; O'Connor, D.G.; King, B.V.; Kisi, E.H. Damage accumulation and recovery in C+-irradiated $\mathrm{Ti}_{3} \mathrm{SiC}_{2}$. Acta Mater. 2014, 66, 317-325. [CrossRef]

53. Liu, C.; Shi, L.; Qi, Q.; O'Connor, D.G.; King, B.V.; Kisi, E.H.; Qing, X.B.; Wang, B.Y. Surface damage of $\mathrm{Ti}_{3} \mathrm{SiC}_{2}$ by $\mathrm{MeV}$ iodine bombardment. Nucl. Instrum. Methods Phys. Res. Sect. B Beam Interact. Mater. Atoms 2013, 307, 536-540. [CrossRef]

54. Bentzel, G.W.; Ghidiu, M.; Anasori, B.; Barsoum, M.W. On the interactions of $\mathrm{Ti}_{2} \mathrm{AlC}_{2} \mathrm{Ti}_{3} \mathrm{AlC}_{2}, \mathrm{Ti}_{3} \mathrm{SiC}_{2}$ and $\mathrm{Cr}_{2} \mathrm{AlC}$ with silicon carbide and pyrolytic carbon at $130{ }^{\circ} \mathrm{C}$. J. Eur. Ceram. Soc. 2015, 35, 4107-4114. [CrossRef]

55. Chiker, N.; Haddad, A.; Hadji, Y.; Benammar, M.E.A.; Azzaz, M.; Yahi, M.; Sahraoui, T.; Hadji, M.; Barsoum, M.W. Infiltration behavior of $\mathrm{Cu}$ and Ti fillers into $\mathrm{Ti}_{2} \mathrm{AlC} / \mathrm{Ti}_{3} \mathrm{AlC}_{2}$ composites during tungsten inert gas (TIG) brazing. Ceram. Int. 2018, 44, 3282-3290. [CrossRef]

56. Liu, M.; Chen, J.; Cui, H.; Sun, X.; Liu, S.; Xie, M. Ag/ Ti ${ }_{3} \mathrm{AlC}_{2}$ composites with high hardness, high strength and high conductivity. Mater. Lett. 2018, 213, 269-273. [CrossRef]

57. Septiadi, A.; Fitriani, P.; Sharma, A.S.; Yoon, D.H. Low pressure joining of $\mathrm{SiC}_{\mathrm{f}} / \mathrm{SiC}$ composites using $\mathrm{Ti}_{3} \mathrm{AlC}_{2}$ or $\mathrm{Ti}_{3} \mathrm{SiC}_{2}$ MAX phase tape. J. Korean Ceram. Soc. 2017, 54, 340-348. [CrossRef]

58. Anasori, B.; Xie, Y.; Beidaghi, M.; Lu, J.; Hosler, B.C.; Hultman, L.; Kent, P.R.C.; Gogotsi, Y.; Barsoum, M.W. Two-dimensional, ordered, double transition metals carbides (MXenes). ACS Nano 2015, 9, 9507-9516. [CrossRef] [PubMed]

(C) 2019 by the author. Licensee MDPI, Basel, Switzerland. This article is an open access article distributed under the terms and conditions of the Creative Commons Attribution (CC BY) license (http:/ / creativecommons.org/licenses/by/4.0/). 